KatarZyna LindA-GrycZA

Uniwersytet Gdański

\title{
Ticino, jego mieszkańcy i ich tożsamość językowo-kulturowa
}

$\mathrm{T}$ Ticino $^{1}$ (niem. Tessyn) to najdalej wysunięty na południe region Szwajcarii, oddzielony od pozostałej części Helvetii naturalną, alpejską granicą. Razem z czterema dolinami alpejskimi z sąsiedniego kantonu Gryzonia: Val Mesolcina, Val Calanca, Val Bregaglia i Val Poschiavo, tworzą tzw. Szwajcarię włoskojęzyczną (wł. Svizzera Italiana, por. Lurati 1982). Bez bariery geograficznej Ticino sąsiaduje z Włochami, co przez wieki silnie wpływało na kształtowanie się i umacnianie jego włoskiej tożsamości. Pozostawanie w Konfederacji przy jednoczesnej izolacji od pozostałych kantonów helweckich z jednej strony wpłynęło znacząco na wzmocnienie poczucia odrębności czy wręcz peryferyjności względem krajowego centrum, z drugiej strony pozwoliło jego mieszkańcom na zachowanie odrębności etnicznej, kulturowej i językowej, unikając przy tym wchłonięcia przez silne ośrodki lombardzkie, jak Como czy Mediolan (Kuntz 2008; Porębski 2009). Ticinianie zadbali, by tę odrębność podkreślono możliwie wyraźnie, m.in. przez odpowiednie zapisy w konstytucjach: kantonalnej i szwajcarskiej Ticino to jedyny kanton, który de iure jest całkowicie włoskojęzyczny ${ }^{2} \mathrm{w}$ oficjalnie wielojęzycznej Szwajcarii (Pawłowski 2004).

Region Ticino tylko pozornie jest monojęzykowy. W tym podalpejskim (wł. cisalpine) kantonie językiem włoskim (Lewis, Simons, Fennig 2013) posługują

\footnotetext{
${ }^{1}$ Nazwa regionu Republika Kantonu Ticino (Repubblica e Cantone Ticino) ma popularniejszą, krótszą i - także włoskojęzyczną - wersję: Ticino. Jej niemiecko- i francuskojęzyczny odpowiednik to Tessin, natomiast lombardzki - Tesin. Nazwa pochodzi od przepływającej przez kanton rzeki Ticino (Kuntz 2008).

${ }^{2}$ Oficjalnie wyjątkiem jest jedynie niemieckojęzyczna gmina Bosco Gurin.
} 
się na co dzień głównie mieszkańcy miast; włoski standardowy używany jest przede wszystkim w edukacji, w sytuacjach oficjalnych i do kontaktów międzynarodowych (w tym z turystami z Włoch). Instytucje publiczne i centra biznesowe to miejsca, w których pracownicy poza włoskim posługują się także językiem niemieckim, coraz częściej i angielskim. W Ticino mieszkają również osoby niemieckojęzyczne (głównie osadnicy z niemieckojęzycznej części Szwajcarii, które stanowią mniejszość); wśród nich wyróżniającą się językowo i etnicznie mikromniejszością są Walserowie zamieszkujący położoną wysoko w Alpach wieś Bosco Gurin; dla części jej mieszkańców (głównie osób starszych) archaiczny dialekt niemiecki Walsersprache w miejscowej odmianie to wciąż język najważniejszy (Tomamichel 1976), choć przynajmniej w stopniu biernym władają oni także włoskim. Dialekty lombardzkie (tesyńskie) oraz dialekt wspólny regionu, tzw. koinè ${ }^{3}$, są wciąż używane w Ticino, szczególnie wśród mieszkańców dolin, jednakże nie mają oficjalnego statusu - coraz częściej ludzie stamtąd używają języka włoskiego. Młodzież natomiast coraz częściej używa odmiany tzw. włoskiego popularnego (italiano poppolare), który jest językiem kultury masowej (Porębski 2009).

Mimo formalnej jednojęzyczności region to mozaika egzystujących obok siebie języków ${ }^{4}$. Ticino jest więc de facto miejscem, które można określić jako wielojęzykowe (Wysoczański 2006). Naturalny sposób codziennej komunikacji Ticinian to klasycznie rozumiana dyglosja (Ferguson 1959; Stępkowska 2013), a nawet tryglosja, gdyż używanie poza włoskim w jego różnych odmianach także innego języka (np. niemieckiego lub angielskiego) stanowi element codziennego życia wielu z nich.

To włoski pozostaje jednak najważniejszym językiem dla tożsamości regionu i jego mieszkańców. Mam tutaj na myśli ich tożsamość kulturową, mając na uwadze powiązanie języka z kulturą, choć w historii myśli etnologicznej zdania w kwestii charakteru i zakresu tej relacji były i są podzielone (por. np. Burszta 1986). Słownik etnologiczny podaje, że tożsamość kulturowa to „najważniejszy rodzaj tożsamości zbiorowej, który polega na historycznie uwarunkowanym, kulturowym sposobie zachowania przez daną ludzkość istnienia" (Staszczak 1987). Mieszkańcy Ticino od lat zachowują i aktywnie kreują tożsamość kulturową przez dbanie o znajomość języka włoskiego i związanej z nim kultury regionu. Ta kulturowa tożsamość wybrzmiewa wyraźnie z kilkusetletniej historii Ticino, ze współczesnych realiów etno-i-socjolingwistycznych w tym regionie, a także w kontekście i celach działań lokalnych elit w zakresie regionalnej polityki językowej. Potwierdzają ją

\footnotetext{
${ }^{3}$ Koinè to pojęcie, które wywodzi się z czasów starożytnych, gdy imperium Aleksandra Macedońskiego ujednoliciło język grecki; oznacza jednorodny wariant ponaddialektalny języka, który może stanowić zalążek późniejszego języka literackiego. Szerzej o okolicznościach powstania tego terminu pisał np. Roman Szul (2009).

${ }^{4}$ Patrząc z perspektywy etnologicznej na omawiane w artykule języki Ticino i jego mieszkańców, przyjmuję punkt widzenia użytkowników języka i ważne dla nich kody językowe traktuję jak etnolekty (Majewicz 1989) z równym szacunkiem bez względu na to, czy w kontekście lingwistycznym to np. lokalny dialekt, czy odmiana literacka, uznana przez prawo i mająca status języka.
} 
również sami mieszkańcy Ticino, wśród których prowadziłam badania. Dlatego też, aby podkreślić rolę języka jako najbardziej charakterystycznego wyróżnika kulturowego Ticino, w kontekście ticińskiej tożsamości używać będę określenia: tożsamość językowo-kulturowa.

Na współczesną sytuację językową w Ticino oraz na stosunek jego mieszkańców do wybranych etnolektów mają wpływ nie tylko uwarunkowania historyczne-kulturowe $w$ regionie, ale również kwestie wynikające ze sposobu prowadzenia polityki językowej. Antropologia także interesuje się tym zagadnieniem. Badania z zakresu antropologii polityki językowej i planowania językowego prowadzone są $\mathrm{w}$ różnych kontekstach, $\mathrm{w}$ tym $\mathrm{w}$ mikroskali, zarówno przez badaczy zagranicznych (np. McCarthy, Warhol 2011), jak i polskich (por. np. Linda 2011; Dołowy-Rybiński 2014).

Termin „polityka językowa” rozumiem za Stanisławem Gajdą (1998: 11) jako „ogół działań podejmowanych w pewnej społeczności celem kształtowania stosunku do języka oraz oblicza komunikacji w niej, a także w kontaktach z innymi społecznościami". Przyjmuję, że w kontekście ticińskim bardzo ważna jest mikropolityka językowa: prowadzona lokalnie, np. przez regionalne władze, elity, oraz oddolnie - widoczna jest ona w poglądach i realnych, codziennych wyborach językowych mieszkańców regionu, użytkowników danych etnolektów (Linda 2009).

Celem artykułu jest omówienie oraz analiza tożsamości językowo-kulturowej Ticino i jego mieszkańców. W tekście zostanie zaprezentowany językowy obraz regionu w perspektywie historycznej i współczesnej, a także wyniki badań $\mathrm{w}$ dwóch sferach mikropolityki językowej: 1) prowadzonej w regionie przez przedstawicieli elit/decydentów w tych kwestiach; 2) obecnej w codziennym życiu mieszkańców Ticino: ich decyzjach, poglądach i postawach. Omówienie tych zagadnień opiera się na analizie źródeł wywołanych i zastanych, głównie włoskojęzycznych, ale również niemiecko-, angielsko- i polskojęzycznych, w tym kluczowych dla kwestii językowej tekstów legislacyjnych ${ }^{5}$.

Badania etnograficzne w Ticino prowadziłam w 2009 roku oraz sukcesywnie w latach 2011-20136, łącznie spędzając w Szwajcarii około 6 miesięcy i realizując 54 wywiady. Podczas moich pobytów starałam się być jak najbliżej mieszkańców Ticino. Mieszkałam u włoskojęzycznej ticińskiej rodziny (w Locarno), ale również

\footnotetext{
${ }^{5}$ Mam tutaj na myśli: konstytucję kantonalną (Costituzione della Repubblica e Cantone Ticino), szwajcarską (Konstytucja Federalna Konfederacji Szwajcarskiej) oraz ratyfikowaną przez ten kraj Europejską Kartę Języków Regionalnych lub Mniejszościowych.

${ }^{6}$ Były one współfinansowane ze środków uzyskanych z grantu promotorskiego Ministerstwa Nauki i Szkolnictwa Wyższego, z dotacji Instytutu Etnologii i Antropologii Kulturowej UAM w Poznaniu na rozwój młodej kadry naukowej oraz ze środków programu „UAM: Unikatowy Absolwent $=$ Możliwości". Badania te miały szerszy niż prezentowany $\mathrm{w}$ artykule zasięg tematyczny - obejmowały także zagadnienia formalnoprawnej strony polityki językowej prowadzonej na poziomie krajowym i europejskim, analogiczne badania prowadziłam także w odniesieniu do hiszpańskiej Katalonii. Zrealizowałam również badania ilościowe, by móc oszacować skalę analizowanego zjawiska. W tym artykule prezentuję części wyników badań jakościowych odnoszących się do Ticino i pozyskanych od tamtejszych informatorów oraz ze źródeł zastanych i obserwacji uczestniczącej.
} 
u przedstawicieli migracji zewnętrznej (u chińskiej rodziny w Bellinzonie) i migracji wewnętrznej (rodziny z małej alpejskiej wioski, mówiącej dialektem szwajcarskiego niemieckiego tzw. Schwyzertüütsch). Pobyt u rodzin dawał mi okazje do obserwacji sposobu komunikacji moich współlokatorów w różnych sytuacjach: codziennych i świątecznych, zawodowych i rodzinnych, pomiędzy „swoimi” a osobami z zewnątrz, a także w komunikacji pomiędzy różnymi pokoleniami członków danej rodziny. Prowadziłam także obserwację uczestniczącą, biorąc udział m.in. w świętach lokalnych (m.in. Pane Vino, Rabadan) oraz w wydarzeniach ważnych dla tworzenia lokalnej polityki językowej, jak Tavola Rotonda na lugańskim Università della Svizzera italiana7.

Wielojęzykowość i wielojęzyczność, obecne na co dzień w regionie i życiu jego mieszkańców, nie stoją w sprzeczności z tym, że to włoski uważany jest za najważniejszy język w Ticino i dla Ticinian, co pragnę pokazać w niniejszej pracy. Interesuje mnie także, dlaczego - mimo odrodzenia idei ekologii językowej (Wysoczański 1999) i wyraźnemu zwrotowi w Europie Zachodniej ku językom mniejszościowym i regionalnym, postrzeganym jako dziedzictwo niematerialne (Szmidt, Mejnartowicz 2009) - to właśnie włoski wariant standardowy pozostaje głównym przedmiotem działań ticińskiej polityki językowej. Czy działania regionalnych przedstawicieli „elit” - decydentów polityki językowej Ticino - wpływają na poglądy i postawy mieszkańców względem charakterystycznego dla ich kantonu etnolektu, na ich stosunek do kwestii wielojęzyczności? Czy Ticinianie uważają siebie i swój region za jedno- czy wielojęzyczny? Analizując te kwestie, pragnę przybliżyć się do znalezienia odpowiedzi na pytanie, jaka przyszłość czeka włoską tożsamość językowo-kulturową oraz wielojęzykowość tego regionu.

Ze względu na złożoność tematu i ograniczenia rozmiarowe tekstu, jak również chęć wypełnienia istniejącej luki w polskich publikacjach naukowych poświęconych Ticino ${ }^{8}$, artykuł ma charakter wprowadzający i sygnalizujący potrzebę dalszych badań nad tematyką tożsamości językowo-kulturowej w Ticino w bardziej sprecyzowanych obszarach.

\section{Ticino i jego języki w perspektywie historycznej}

Włoski etnolekt i włoska kultura to podstawowy wyróżnik kulturowy znakomitej większości współczesnych mieszkańców Ticino, jednak nie zawsze tak było, a zmiany następowały stopniowo. Kolebka dzisiejszego Ticino, znajdująca

\footnotetext{
${ }^{7}$ Tavola Rotonda, czyli tzw. Okrągły Stół, było to publiczne spotkanie lokalnych elit politycznych, artystycznych, dziennikarskich oraz edukacyjnych w sprawie omówienia i poddania publicznej debacie najnowszych propozycji działań na rzecz promowania języka włoskiego w Szwajcarii.

${ }^{8}$ Nieliczne wydane w Polsce monografie poświęcone Szwajcarii jedynie wzmiankują o Ticino (np. Wojtowicz 1989); nieco więcej napisali np. Stępkowska (2009) czy Porębski (2009), ale piszą oni o „włoskojęzycznych Szwajcarach”; mimo tak podkreślonej kwestii językowej Porębski pisze o regionie i jego mieszkańcach, posługując się nazwą niemieckojęzyczną, odpowiednio: Tessyn i Tessyńczycy.
} 
się na północy regionu Dolina Lewantu, stanowiła przez kilka wieków jedyną drogę z pozostałą częścią Helwecji, jak również ważny szlak handlowy. Prawdopodobnie tą drogą dotarły na tereny Ticino dzieła literatury włoskiej (toskańskiej), z których fragmenty można odnaleźć w papierach miejscowych pisarzy sądowych (Lurati 1976). Pierwsze dokumenty z terenu obecnego Ticino, które zostały napisane we wczesnym tessyńskim włoskim pochodzą z drugiej połowy XV wieku (Ceschi 2006). W tym okresie tereny dzisiejszego Ticino należały jeszcze do Księstwa Mediolanu (Kuntz 2008). Po przyłączeniu w 1403 roku obszaru Doliny Lewantu do Konfederacji językowa niezależność jej mieszkańców została uznana przez nową władzę (Pedrazzini 1952).

Rozprzestrzenianie się języka włoskiego wśród ludności Ticino postępowało wraz z procesem alfabetyzacji. W XVI i XVII wieku zataczała ona coraz szersze kręgi. W edukacji zastosowano przepisy kontrreformacyjne, co zaowocowało m.in. pojawieniem się świeckich ${ }^{9}$, dobrze wykształconych nauczycieli. Natomiast wśród miejscowej ludności widoczna była większa chęć do przemieszczania się, a wraz z fenomenem migracji konieczne było opanowanie umiejętności czytania i pisania, pozwalających na komunikowanie się (Lurati 1994). W dalszej ekspansji włoskiego ważną rolę odgrywały kazania, które wygłaszane były przez księży właśnie w tym języku. Rozwijały one u wiernych głównie pasywną kompetencję w zakresie rozumienia tego języka. Wpływ na rozprzestrzenianie włoskiego miały także metody nauczania doktryny chrześcijańskiej, praktykowane m.in. w szkołach parafialnych, bazujące na zapamiętywaniu oraz recytowaniu fragmentów tekstów napisanych w języku włoskim (Bianconi 1989).

Na przestrzeni XVIII stulecia języka włoskiego - normy toskańskiej - używali m.in. notariusze, wyedukowani kupcy handlujący w regionie oraz za granicą, jak również kobiety ze znaczących rodzin. Natomiast piśmienne, ale mniej zamożne osoby, w dużej mierze emigranci, tworzyli swoje teksty w języku włoskim, bardzo zbliżonym do języka mówionego (Lurati 1994). W życiu codziennym mieszkańców Ticino zdecydowanie dominował dialekt. Uważny obserwator z tamtych czasów, pastor z Zurychu, Hans Rudolf Schinz, który spędził tam kilka miesięcy w latach 70. XVIII wieku, zauważył, że Ticinianie:

kiedy są w towarzystwie cudzoziemców, mówią w sposób o wiele bardziej staranny, poprawny i elegancki niż Mediolańczycy i Piemontczycy, nawet i zwykli ludzie posługują się dobrym włoskim, ponieważ muszą się przyuczyć, aby być lepiej rozumianymi podczas emigracji (Schinz 1985: 282).

Zachowanie Szwajcarów wydawało się być pełne szacunku w stosunku do specyfiki włoskojęzycznych mieszkańców. Tym niemniej odnotowano przypadki narzucania języka niemieckiego w sprawach prowadzonych przed instancjami prawnymi za Alpami, głównie w pierwszych dziesięcioleciach XVI wieku

\footnotetext{
${ }^{9}$ Wcześniej, przez długie lata, przedstawiciele tego zawodu pracujący na terenie Ticino byli niemal wyłącznie duchownymi, którzy nie byli wykształconymi nauczycielami.
} 
(Bianconi 2001). W szkołach benedyktyńskich w Bellinzonie nauczano języka niemieckiego, począwszy od XVII wieku. Znali go i używali również znaczący obywatele Ticino, m.in. notariusze.

W 1804, rok po utworzeniu Kantonu Ticino, została ustanowiona instytucja obowiązkowej szkoły publicznej. Miała ona działać w każdej gminie, a edukacja obejmowała nauczanie czytania, pisania oraz zasad matematyki. Zostały opracowane podręczniki szkolne, debatowano również na temat wykształcenia, metod nauczania języka włoskiego, a także najodpowiedniejszych do tego celu materiałów dydaktycznych i gramatycznych (Catricalà 1995).

W sferze zainteresowań naukowych znalazły się lokalne etnolekty. Zorganizowane zostały badania dialektologiczne nad wpływem włoskiego na lokalny język mówiony, przy których pracował Stefano Franscini - najbardziej znany pisarz i działacz ticiński tego okresu. Prowadzono także studia na temat dialektów szwajcarskich, łącznie z tymi szwajcarsko-włoskimi ${ }^{10}$. Badania te pokazały, że włoski nie był jeszcze wszędzie dobrze znany w sposób czynny, często jednak ludność wykazywała się bierną jego znajomością (Franscini 1989).

W XIX wieku włoski rozprzestrzeniał się na obszarze Ticino coraz bardziej. Przykładowo, Kodeks Karny Republiki i Kantonu Ticino (Codice penale della Repubblica e Cantone Del Ticino), wydany w Lugano w 1816 roku, został zredagowany po włosku. Gazety, almanachy popularne, modlitwy, pieśni liturgiczne oraz literatura popularna przyczyniały się do przybliżania języka włoskiego Ticinianom, szczególnie tym wykształconym.

W międzyczasie definitywnie zmieniły się relacje pomiędzy Szwajcarią a Włochami oraz Lombardią austriacką, do czego przyczyniły się m.in. nasilające się dążenia irredentystyczne nacjonalistów włoskich, a także centralistyczny charakter konstytucji szwajcarskiej ograniczający regionom możliwość samodzielnych kontaktów z sąsiednimi krajami (1847). Obszar graniczny między państwami, którego duża część przypadała koło Ticino, zasiedlały liczne mniejszości językowe i kulturalne. Mimo animozji międzypaństwowych na początku XX wieku kanton otworzył się na współpracę z Włochami, głównie z powodu obawy przed postępującą germanizacją regionu. W 1880 roku na tysiąc mieszkańców Ticino przypadało 989 osób włoskojęzycznych. Natomiast w 1920 roku ich liczba zmniejszyła się do 933, podczas gdy liczba mieszkańców kantonu mówiących po niemiecku wzrosła do około 5,5\% (Lurati 1976).

25 kwietnia 1914 roku, w nowo powstałym czasopiśmie tessyńskim „L’Àdula”, ukazał się artykuł Carlo Salvioni zatytułowany Uwarunkowania kultury włoskiej $w$ Kantonie Ticino (Le condizioni della cultura italiana nel cantone Ticino), analizujący czynniki mające negatywny wpływ na włoską kulturę - w tym przede wszystkim na język w Ticino ${ }^{11}$. Pośród nich Salvioni wymieniał m.in. prowadzenie przez Konfederację intensywnej polityki centralistycznej; podejmowanie przez

${ }^{10}$ Przykładem może być dzieło Franza J. Staldera Die Landessprachen der Schweiz oder schweizerische Dialektologie wydane w Aarau w 1819 roku.

${ }^{11}$ Artykuł napisany został pierwotnie do działu poświęconego Ticino we włoskiej gazecie „Dante Alighieri”, następnie przedrukowano go w ticińskiej „Adula”. 
młodą tessyńską inteligencję studiów w Szwajcarii (w języku niemieckim), nie zaś we Włoszech ${ }^{12}$; , ,antywłoską" atmosferą panującą w szkołach w Ticino, związaną z sytuacją polityczną Włoch oraz kolonialną politykę prowadzoną przez firmę Gotthardbahn ${ }^{13}$, która sprowadziła do Ticino silne ekonomicznie kolonie niemieckojęzyczne (Bianconi 2001).

Były to czasy, gdy społeczność inteligencji Ticino stanęła przed trudnym dylematem. Z jednej strony pragnęła uniknąć izolacji od Włoch, mimo że jako kraj faszystowski nie stanowiły już one wzoru na polu ideologicznym czy też kulturowym. Z drugiej strony chcieli przeciwstawić się polityce rządu szwajcarskiego, który od I wojny światowej wprowadził nowe, niekorzystne dla ekonomii lokalnej Ticino taryfy celne. Żądania i sugestie wysuwane przez Ticinian w stosunku do rządu centralnego zostały zredagowane w dokumencie o nazwie Postulaty tessyńskie (Rivendicazioni ticinesi) z 1925 roku $^{14}$. Jednym z głównych propagatorów tej inicjatywy był poeta ze Szwajcarii włoskojęzycznej, Francesco Chiesa. W piśmie mieszkańcy Ticino otwarcie zwracali się do Berna o pomoc i ochronę na polu ekonomicznym i lingwistycznym: przykładowo, jedna z próśb dotyczyła zamknięcia szkół niemieckojęzycznych, utworzonych w Ticino po otwarciu tunelu kolejowego wiodącego przez Przełęcz Świętego Gotarda. W obliczu zagrożenia ze strony silnej pozycji niemieckiego w ekonomii i turystyce w 1931 roku rząd tessyński zagłosował nad dekretem w obronie języka włoskiego (Lurati 1976).

W październiku 1933 roku rozpoczęło nadawanie Radio Monte Ceneri ${ }^{15}$, istniejące do dzisiaj pod nazwą: Szwajcarskie Radio w Języku Włoskim. Stało się ono symbolicznym wsparciem dla jedności Konfederacji, pełniło także ważną rolę $\mathrm{w}$ popularyzowaniu i rozprzestrzenianiu się języka włoskiego na terenie kraju. Politycy oraz edukatorzy myśleli o języku włoskim w duchu podobnym do radiowców. W 1951 roku Departament Edukacji Publicznej Kantonu Ticino opublikował Gramatykę włoska dla szkót wyższych i gimnazjów (Grammatica italiana: per le Scuole Maggiori e i Ginnasi). Książka autorstwa Bruno Migliorini i Giuseppe Mondada została opracowana według językowej normy toskańskiej, a na swoich stronach zapraszała do poprawiania „prowincjonalizmów". Podawała także przykłady najczęstszych błędów z zakresu wymowy oraz składni, popełnianych przez Ticinian w codziennych konwersacjach wraz z sugestiami poprawy (Beffa 2015).

Od lat 50. XX wieku wśród Ticinian pojawiły się obawy przed utratą dialektów, lokalnej tożsamości, przed swoistą katastrofą etniczno-lingwistyczną. Główną ich przyczyną były - i z przerwami trwające do dzisiaj - migracje: przybywanie i osiedlanie się na terenie "szwajcarskiej Lombardii” osób niemieckojęzycznych z północy oraz włoskojęzycznych z południa. Jak pisze Sandro Bianconi (1994: 18),

\footnotetext{
${ }^{12} \mathrm{Na}$ obszarze Ticino pierwsza uczelnia wyższa pojawiła się dopiero pod koniec XX wieku, do tego czasu lokalna młodzież wybierała studia w innych kantonach, gdzie nauka prowadzona była głównie w języku niemieckim.

${ }^{13}$ Była to prywatna firma zarządzająca kolejami, która zatrudniała około 1500 osób, głównie niemieckojęzycznych.

${ }^{14} \mathrm{Od}$ tej daty, prośby i uwagi jeszcze kilkukrotnie kierowane przez władze regionalne Ticino do Berna są redagowane $\mathrm{w}$ formie kolejnych edycji tego dokumentu.

${ }^{15}$ Szwajcarska telewizja włoskojęzyczna pojawiła się dopiero w 1961 roku.
} 
dialekt został zredukowany do roli ",symbolicznego bohatera zderzenia przeszłości z teraźniejszością", mimo że już pod koniec lat 80. powstała „rzeczywistość otwarta, wielokulturowa i wielojęzyczna, zaś język włoski stał się językiem «macierzystym» dla nowej generacji ludzi żyjących w Ticino" (Bianconi 1994: 20).

Problem obaw przed "germanizacją" pozostawał szczególnie aktualny w latach 70. XX wieku, kiedy sytuacja socjolingwistyczna regionu drastycznie się zmieniła. Germanofoni zasiedlali głównie miejsca atrakcyjne turystycznie. Ze względu na wspaniałe warunki geograficzno-przyrodnicze liczni niemieckojęzyczni Szwajcarzy wybierali (i wciąż obierają) Ticino za cel przeprowadzki na emeryturę, do położonych m.in. wokół jeziora Locarno wygodnych willi zwanych Seniorenresidenzen. Niewielu $\mathrm{z}$ nich jednak podejmowało trud nauczenia się choć podstaw języka włoskiego, co mocno raziło lokalną społeczność.

Podobnie negatywnie odbierane było wśród Ticinian zachowanie kelnerów pracujących w barach w Asconie, którzy zwracali się do wszystkich - turystów oraz mieszkańców Ticino - wyłącznie po niemiecku. Ticinianie w tamtym okresie byli „dalecy od stwierdzenia, że kwestia języka włoskiego w Ticino nie stanowi problemu" (Lurati 1976: 129), uważali wręcz, że "staje się to ewidentnym problemem szwajcarskiej wspólnoty włoskiej oraz zdefiniowania i utrzymywania własnej tożsamości" (Bianconi 1980: 8).

Współcześnie język niemiecki w kantonie Ticino nie jest odbierany przez jego mieszkańców jako zagrożenie, gdyż to włoski jest powszechnie używany i dodatkowo prawnie chroniony. Postanowienia regulujące funkcjonowanie polityki językowej, sprzyjające włoskiemu w Ticino, zostały uchwalone aż na trzech poziomach: ponadpaństwowym ${ }^{16}$, krajowym oraz regionalnym. Najważniejszą rolę odgrywają dokumenty ustanowione na poziomie państwowym (centralnym). To konstytucja stała się bazą powstania tzw. Szwajcarii czterojęzycznej, z językiem włoskim jako jednym z jej języków urzędowych i oficjalnych na całym terenie kraju. Dokument ten jednocześnie uznaje kanton Ticino za jednojęzyczny, wyraźnie tym samym akcentując dominację i specjalny przywilej dla języka włoskiego.

Zapisy specjalne istnieją również na poziomie regionalnym, jednak są one nieliczne, a ich oddziaływanie jest ograniczone do obszaru kantonu. Konstytucja Republiki oraz Kantonu Ticino z 14 grudnia 1997 roku zawiera tylko jeden zapis dotyczący kwestii językowej $\mathrm{w}$ Ticino. Ujmuje go natomiast na samym początku dokumentu, już w pierwszym artykule, który orzeka, że Ticino jest demokratyczną republiką o języku i kulturze włoskiej: Il Cantone Ticino è una repubblica democratica di cultura e lingua italiane (art. 1). Ustawodawstwo kantonu nie zawiera

\footnotetext{
${ }^{16}$ Przykładowo, Konfederacja Szwajcarska podpisała Europejską Kartę Języków Regionalnych lub Mniejszościowych 8 października 1993 roku. Władze centralne kraju formalnie ratyfikowały ją 23 grudnia 1997 roku, natomiast jej postanowienia weszły w życie 1 kwietnia 1998 roku. Dzięki podpisaniu przez Szwajcarię tego dokumentu Ticino otrzymuje z puli centralnej kraju dodatkowe środki pieniężne na promocję oraz utrzymanie żywotności języka włoskiego, jak również, choć w ograniczonym zakresie, języka Walserów - mniejszości językowej z wioski Bosco Gurin.
} 
żadnej konkretnej ustawy językowej, natomiast ujmuje różne przepisy prawne dotyczące języka w kontekście edukacji, sprawiedliwości i kultury.

Istnieją także wzmianki prawne odnoszące się do kwestii języka włoskiego dla imigrantów. Ustawa o szkolnictwie z 1 lutego 1990 roku (ustęp 72.1) stanowi, że w szkołach wszystkich poziomów możliwe jest zorganizowanie lekcji języka włoskiego dla uczniów posługujących się innym językiem, którzy mają trudności $\mathrm{z}$ nadążeniem za tempem nauki w klasie; $w$ szczególności aby wspierać integrację uczniów z krajów niewłoskojęzycznych przy jednoczesnym poszanowaniu ich tożsamości kulturowej. Ustalenia szczegółowe dotyczące zajęć języka włoskiego i działań integracyjnych są określone w rozporządzeniu z 31 maja 1994 roku w sprawie zajęć języka włoskiego i integracji.

\section{Ticinanie i język(i) dzisiaj - zarys etno/socjolingwistyczny}

Pod względem politycznym Ticinianie uważają się za Szwajcarów, razem z niemiecko-, francusko- i retoromańskojęzycznymi obywatelami tworzą wspólny naród państwowy na podstawie Willensnation. Natomiast kulturowo Ticinianie są włoscy. Ich włoskość opiera się nie tylko na poczuciu wspólnotowości kultury i tradycji z sąsiadującym krajem. Przede wszystkim bazuje ona na wspólnym, wyróżniających ich na tle mieszkańców pozostałych kantonów Szwajcarii języku, z którym związani są od wielu wieków. Język i włoskość to bez wątpienia najważniejszy wyróżnik tożsamości Ticinian.

Wspólnoty wyobrażone, nazwane tak przez Benedicta Andersona (1997), ujawniały zasadę tworzenia się narodów przez zaszczepianie ludziom wyobrażenia o ponadlokalnej wspólnocie, którą tworzą. Wydobywały też kreacyjny charakter wyobraźni, która potrafiła wiązać abstrakcyjne kategorie narodu, państwa i narodowej ojczyzny z jakimś realnym obszarem. Jednocześnie uruchamiała narrację o tożsamości, konieczną, by scalić naród. Podobną analogię chciałabym odnieść do poszukiwań wspólnej tożsamości na poziomie ponadlokalnym - chociaż nie państwowym - jaki stanowi wspólnota regionalna. Jeśli jej najważniejszy trzon - element od wieków łączący od wewnątrz, a jednocześnie różnicujący od zewnątrz - stanowi grupa etniczna o wspólnym języku, może on, jak w przypadku Ticinian, stać się ich najważniejszym wyróżnikiem kulturowym i elementem tożsamości regionalnej.

U progu trzeciego milenium nieco ponad 83\% populacji kantonu podalpejskiego mówi po włosku. Zmniejszyła się nieco liczba osób mówiących po niemiecku: 8,3\% w stosunku do danych z drugiej połowy XX wieku, natomiast zwiększa się liczba języków niepaństwowych (USTAT 2015). Wzrost italofonii działa na niekorzyść dialektów, a włoski traci stopniowo swój charakter regionalny.

Tylko w społeczności niemieckojęzycznych imigrantów utrzymał się fenomen względnej jednojęzyczności - jest to bowiem grupa w dużej części zamknięta, ze względów prestiżowych oraz ekonomicznych izolująca się od lokalnej społeczności. Natomiast w aspekcie ogólnym wzrasta wielo- oraz dwujęzyczność. 
Ta druga najczęściej występuje w parach językowych: włoski - inny język, włoski - dialekt. Tendencja ta była widoczna już pod koniec ubiegłego wieku: w 1990 roku około jedna piąta mieszkańców Ticino rozmawiała w domu więcej niż jednym językiem (Moretti, Antonini 2000).

Dialekt, a właściwie koinè dialektalna, nadal, choć w bardziej ograniczonym zakresie, współistnieje z językiem włoskim. Widoczna jest tendencja do wycofywania go z życia publicznego i używania wyłącznie w sytuacjach prywatnych. W 1990 roku mniej niż połowa mieszkańców Ticino - tych mieszkających bardziej w dolinach niż w miastach - potwierdzała, że go używa, podczas gdy $80 \%$ deklarowało, że mówi (również) po włosku (Moretti, Antonini 2000).

Wartą podkreślenia kwestią językową w Ticino jest fakt, że Ticinianie, mówiąc o włoskim, którego używają w życiu codziennym, mają na myśli odmianę tego języka charakterystyczną dla regionu, chociaż badacze przyznają, że w ostatnich latach widać tendencję do jego deregionalizacji (Bianconi 2001). Włoski język regionalny w Ticino przejął wiele galicyzmów oraz germanizmów, poprzez kontakty instytucjonalne, biurokratyczne, handlowe, jak również częściowo poprzez licznych turystów oraz imigrację niemieckojęzyczną. Język jest zrozumiały dla Włochów, natomiast jest bogaty w "tessynizmy" - słowa oraz zwroty, które we Włoszech, ale i w samym Tessynie bywają przedmiotem zaciekawienia i żartów ${ }^{17}$.

Zgodnie z danymi uzyskanymi w spisie powszechnym z 2000 roku znacząco spada liczba osób niemieckojęzycznych we wsi Bosco Gurin. Jest to zjawisko zachodzące od niedawna, biorąc pod uwage prawie dziewięćsetletnią, nieprzerwaną obecność stałej liczebnie grupy niemieckojęzycznych Walserów w Ticino, których język wywodzi się od starego dialektu z kantonu Wallis (Gilardino 2005). Jeszcze w 1990 roku, jak pokazują dane z ówczesnego spisu powszechnego, niemiecki był językiem dominującym wśród mieszkańców Bosco Gurin.

W ciągu zaledwie dekady proporcje zostały odwrócone: w porównaniu do 1990 roku, kiedy to niemieckojęzycznych było 35, a włoskojęzycznych 20 mieszkańców Bosco Gurin, w 2000 roku we wsi odnotowano 37 mieszkańców włoskojęzycznych oraz 23 niemieckojęzycznych. Odzwierciedla to wyraźnie poważną zmianę w strukturze społecznej wsi, która zaszła tam w drugiej połowie lat 90. minionego wieku. Wówczas osiedlili się tam nowi, włoskojęzyczni mieszkańcy, natomiast wielu młodych ludzi wyjechało (Stähli 2011). Niemiecki pozostał na razie językiem używanym przez większość mieszkańców pomiędzy 50. a 70. rokiem życia. Osoby w wieku średnim używają obu języków, jednak preferują włoski, podczas gdy nieliczni najmłodsi mieszkańcy - osoby do 20. roku życia - są już włoskojęzyczne, zaś znajomość języka niemieckiego posiadają głównie na poziomie biernego rozumienia (Stähli 2011).

${ }^{17}$ Ciekawy rysunek satyryczny przedstawiono np. w książce Lo svizzionario (Savoia, Vitale 2008: 60-61). Opatrzony tytułem Che ti ridi? Ho letto la vignetta autostradale (Co cię tak śmieszy? Przeczytatem "winietę" autostradowa) obrazuje on komizm wynikający z dwuznaczności słowa vignetta, które w odmianie włoskiego z Ticino oznacza naklejkę symbolizującą opłatę za korzystanie $\mathrm{z}$ autostrady, natomiast w standardzie języka z Włoch oznacza satyryczny rysunek, komiks. 


\section{Mikropolityka językowa - działania na rzecz języków w Ticino}

Artykuł $1 \mathrm{w}$ paragrafie 1 Konstytucji Kantonu Ticino ${ }^{18} \mathrm{w}$ wyraźny sposób odnosi się nie tylko do języka, ale także do kultury włoskiej. Odzwierciedla to ważne zobowiązanie, które władze i mieszkańcy Ticino przyjęli, by zapewnić tym samym, że ta językowo-kulturowa tożsamość będzie w sposób nieustanny i efektywny promowana. Artykuł ten jest jednym z najważniejszych, ale też nielicznych uregulowań, które mówią o roli języka włoskiego w regionie. Tym samym tkwi w nim zalążek świadomie planowanej i poddawanej regulacjom polityki językowej regionu, której celem byłoby przede wszystkim zachowanie historycznie utrwalonego, italskiego charakteru regionu oraz promocja kultury i języka włoskiego. Kwestie językowe określa przede wszystkim konstytucyjna włoskojęzyczność kantonu, zagwarantowana na szczeblu regionalnym i państwowym, natomiast przy padki szczególne w ramach poszczególnych sfer życia społecznego regulują szczegółowe uchwały.

Jedną z nielicznych dziedzin, $\mathrm{w}$ ramach których pewien zakres ustanowień prawnych reguluje rolę i miejsce określonych języków w życiu Ticinian, jest edukacja. W ustawie o szkolnictwie z 1 lutego 1990 roku, w artykule 1, paragrafie 3, mowa jest o tym, że na terenie szkół kantonalnych wszelkie instrukcje powinny być udzielane po włosku $\mathrm{w}$ imię przestrzegania zasad wolności sumienia: L'insegnamento e impartito in lingua e nel rispetto della liberta di conscienza (Legge della scuola del 1 febbraio 1990). Po założeniu pierwszego uniwersytetu w kantonie, USI - Università della Svizzera italiana, przepis ten został uzupełniony o jeszcze jeden odzwierciedlający tę zmianę, rozszerzający zakres używania włoskiego w szkolnictwie, obejmując nim także nauczanie na poziomie wyższym: L'insegnamento universario è altre forme d'insegnamento superiore nelle lingue regionali o minoritarie (Legge della scuola del 1 febbraio 1990).

Podobnie stwierdza prawo o uczelniach wyższych z 1995 roku, które mówi, że oficjalnym językiem uczelni jest włoski. Tymczasem oferowany przez USI program nauczania, jak również treść uczelnianej strony internetowej, są de facto dwujęzyczne. Warto tutaj zaznaczyć także, że drugim z oferowanych języków nie jest żaden spośród oficjalnych języków Konfederacji, lecz język angielski. Rektor USI, Piero Martinoli, podczas publicznej debaty Tavola Rotonda ${ }^{19}$ tłumaczył, że uczelnia, chcąc być atrakcyjna na arenie międzynarodowej oraz by przyciągnąć zagranicznych badaczy, musi oferować bogaty program w języku angielskim.

\footnotetext{
${ }^{18}$ Costituzione della Repubblica e Cantone Ticino.

${ }^{19}$ Cytaty i nawiązania do tego wydarzenia pochodzą z notatek i nagrań audio wykonanych przeze mnie $\mathrm{w}$ czasie tego spotkania $\mathrm{w}$ ramach prowadzonych badań terenowych. Spotkanie odbyło się w Lugano we wrześniu 2012 roku.
} 


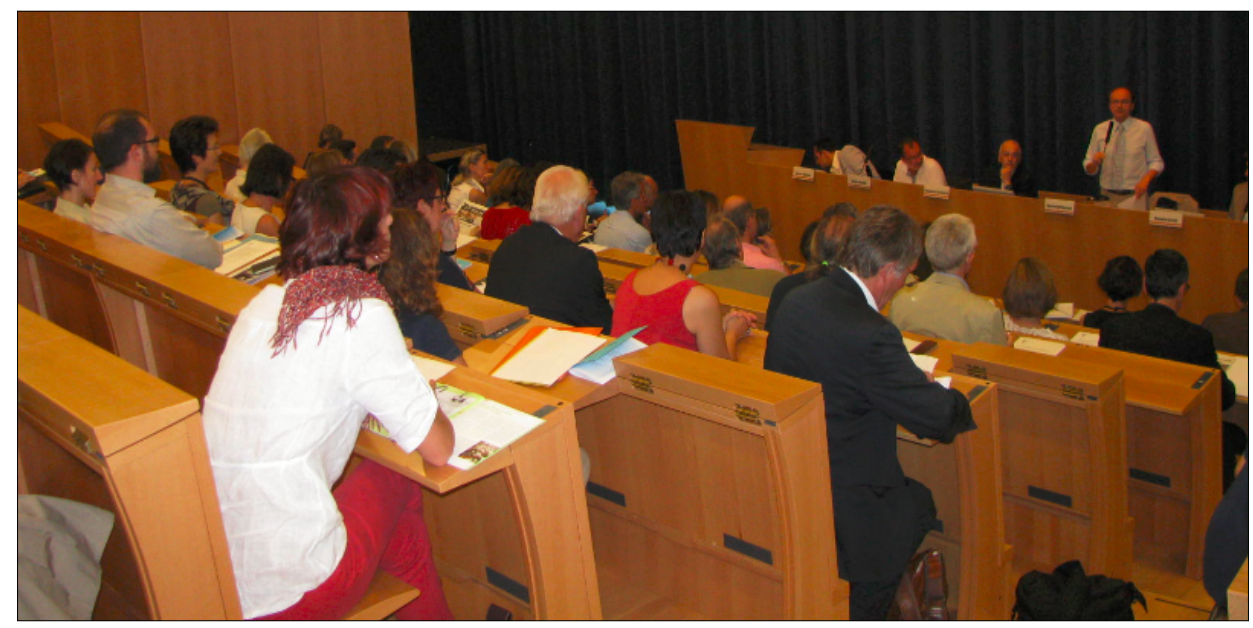

Fot. 1. Spotkanie Tavola Rotonda. Lugano 2012. Źródło: archiwum autorki

Wielu zebranych na sali osób - aktywnych działaczy na rzecz podniesienia statusu języka włoskiego w Szwajcarii - wyraziło dezaprobatę w kwestii tej argumentacji, podkreślając konieczność używania przede wszystkim języka włoskiego na lugańskim uniwersytecie. Jako instytucja ważna dla regionu Ticino, uczelnia ta powinna aktywnie promować język włoski. Jak się okazało, osiągnięcie tego celu stanowi jeden z trzech czołowych projektów uniwersytetu (obok rozwijania bazy dla nauk informatycznych i medycznych). Pierwszy krok w kierunku budowania mocnej pozycji dla włoskiego został postawiony w 2007 roku przez założenie na USI Instytutu Studiów Włoskich. Kolejny zaś stanowi dołączenie do oferty studiów italianistyki, którą można studiować od września 2012 roku zapisało się wówczas na nią 35 osób.

Ustawa z 19 kwietnia 1966 roku o postępowaniu w sprawach administracyjnych stanowi podstawę prawną do zastosowania języka włoskiego w kontaktach oficjalnych z władzami kantonalnymi i lokalnym. Artykuł 8 ustawy stanowi o tym, że wnioski i aplikacje w taki sam sposób jak skargi oraz ogólnie wszystkie roszczenia mogące zostać rozwiązane decyzją władz kantonalnych, miejskich, obywatelskich lub parafialnych, lub decyzją innych organów podobnych instytucji publicznych, muszą być sporządzone w języku włoskim.

W kantonie Ticino publikowane są trzy dzienniki w języku włoskim, tymczasem przed 1995 roku było ich pięć. Ponadto istnieje duża liczba czasopism w języku włoskim wydawanych raz na dwa tygodnie, raz na trzy tygodnie, raz na miesiąc i raz na dwa miesiące, natomiast bardzo niewiele tytułów ukazuje się w innych językach. Przykładem może być niemieckojęzyczny „Tessiner Zeitung”, wydawany co tydzień w piątek. Warto zaznaczyć, że mimo postępującej cyfryzacji (Casoni 2003) Ticino jest jednym z regionów Europy o największej liczbie publikacji prasowych.

Manuele Bertoli, dyrektor Wydziału Edukacji, Kultury i Sportu Kantonu Ticino, w swoich wystąpieniach publicznych często podkreśla, że język włoski nie 
stanowi osobliwości ich regionu, ale jest zasadniczą częścią oryginalnego DNA Szwajcarii federalnej. Dlatego też polityka państwowa powinna jasno określić, czy zamierza zaproponować pewnego rodzaju mutację genetyczną tego DNA, czy też naprawdę zadziałać, ponieważ jak do tej pory mamy do czynienia z retoryczną grą Szwajcarii bazującą na wielojęzykowości oficjalnych przemówień, a następnie, nawet $w$ niezbyt zawoalowany sposób, robiącą coś zupełnie innego (Tavola Rotonda 2012).

Przedstawiciel lokalnego urzędu wyznaczył również trzy drogi w działaniach na rzecz podniesienia prestiżu języka włoskiego: po pierwsze, jest to praca na polu polityki, by włoski stał się naprawdę trzecim oficjalnym językiem; po drugie, należy udzielić wsparcia dla kultury italofońskiej w całej Szwajcarii przez większą obecność tego języka w ogólnokrajowym radiu i telewizji; po trzecie, jest to intensywna współpraca ze szkołami mająca na celu stworzenie systemu wymian pomiędzy młodzieżą z różnych regionów językowych Szwajcarii. Bertoli zaznaczył również, że na wszystkich tych trzech polach powinno się działać głównie poza Alpami, tam gdzie jeszcze zbyt często „Szwajcaria uważana jest za kraj dwujęzykowy" (Tavola Rotonda 2012).

Problemem centralnie prowadzonej polityki językowej pozostaje ograniczanie środków ekonomicznych na pełne włączenie języków mniejszościowych, $\mathrm{w}$ tym włoskiego, $\mathrm{w}$ administrację federalną na poziomie dostępności dokumentów we wszystkich czterech językach Szwajcarii. Tłumaczenia na język włoski są publikowane z opóźnieniem, zmuszając przedstawicieli administracji regionalnej do używania języka niemieckiego, rzadziej - francuskiego. Brakuje także tekstów pisanych na bieżąco po włosku tak, by nie było konieczności ich tłumaczenia.

Problemy te odnoszą się również do sfery nowych mediów komunikacji. Strony internetowe wielu instytucji o zasięgu ogólnokrajowym są dostępne jedynie po niemiecku i francusku, a rzadziej spotykanym, trzecim językiem tłumaczenia witryn internetowych nie jest język włoski, lecz angielski. Najczęstszym przypadkiem jest całkowita nieobecność języka Dantego w tej sferze. Spotykane są jedynie takie sytuacje, gdy w języku włoskim dostępna jest ograniczona treść, np. wyłącznie strona domowa.

Badania na ten temat prowadzone były przez Obserwatorium Językowe Szwajcarii Włoskojęzycznej (Osservatorio linguistico della Svizzera italiana, OLSI), która ma swoją siedzibę w stolicy Ticino, Bellinzonie. Wykazały one, że względny balans w sferze obecności włoskiego na stronach internetowych, obok pozostałych języków oficjalnych Federacji, występuje na stronach administracji federalnej, natomiast jest całkowicie zaburzony na niekorzyść włoskiego w innych jednostkach oraz sektorach (Casoni 2003). Warto w tym miejscu zauważyć, że strony ważniejszych instytucji z Ticino są prawie wyłącznie włoskojęzyczne.

Władze kantonu Ticino uważają, że włoski - jako język mniejszościowy, ale jednocześnie oficjalny język Konfederacji - powinien znaleźć się w programie nauczania w szkołach na terenie regionów niewłoskojęzycznych Szwajcarii, aby każdy obywatel Szwajcarii posiadał przynajmniej podstawową znajomość języka 
włoskiego. Będzie to również owocowało lepszą komunikacją pomiędzy mieszkańcami różnojęzycznych regionów.

Oprócz wymienionych środków nauczania języka kanton zachęca do nauki włoskiego na różne sposoby: przez promowanie wymian indywidualnych i klasowych oraz przez wspieranie inicjatyw nauczania dwujęzycznego i innych innowacji. Artykuł 13 prawa o szkolnictwie z 1 lutego 1990 roku pozwala na takie innowacje i eksperymenty jak edukacja dwujęzyczna przez dofinansowanie kursów językowych w innych częściach Szwajcarii i za granicą czy też wspieranie inicjatyw prywatnych takich jak ,Języki i sport”, która od ponad 20 lat organizuje kursy sportowo-językowe (w języku niemieckim, francuskim $\mathrm{i}$ angielskim) w okresie wakacji letnich. Te cieszące się dużym powodzeniem wyjazdy, pierwotnie przeznaczone dla uczniów szkół średnich, zostały obecnie rozszerzone na poziom szkoły podstawowej.

W sferach życia gospodarczego i społecznego, kształcenia, kultury oraz $\mathrm{w}$ innych budowane są bardzo aktywne wymiany transgraniczne między kantonem Ticino a Włochami, zwłaszcza z sąsiednimi prowincjami włoskimi, które z kantonem Ticino tworzą Regio Insubrica. Współpraca między Ticino a lokalnymi władzami włoskimi stopniowo rozszerza się w licznych obszarach. Rozporządzenie z mocą ustawy z 10 marca 1998 roku, które uwzględnia Umowę Ramową o Współpracy Transgranicznej zawartą między rządem Republiki Włoskiej a Konfederacją Szwajcarską w 1993 roku, reguluje wieloletnie szczególne stosunki, które wyrosły między kantonem Ticino i gminą Campione we Włoszech.

W swojej walce o lepszą pozycję włoskiego na terenie Szwajcarii władze Ticino mają oparcie prawne w postaci Federalnego Prawa o Językach Narodowych i Porozumieniu między Społecznościami i Językami, uchwalonym 5 października 2007 roku. W wyraźny sposób podkreśla ono wsparcie na poziomie państwowym dla języków mniejszościowych oraz wielojęzyczności, w tym subwencję finansową na rzecz języka włoskiego. Sprawozdania roczne Wydziału Edukacji, Kultury i Sportu dla Federalnego Urzędu Kultury opisują liczne działania językowo-kulturalne kantonu, a także to, w jaki sposób Ticino korzysta z pomocy finansowej, którą otrzymuje od Konfederacji dla ochrony swojego języka i kultury. W szczególności wsparcie to finansuje prace wspomnianej już jednostki badawczej Osservatorio linguistico della Svizzera italiana, jak też różne inne projekty badawcze.

Niektóre badania zarekomendowane przez władze Ticino wzbudzają silne zainteresowanie także poza społecznością akademicką, będąc pozytywnie odbieranymi przez znaczną część mieszkańców Ticino. Na przykład księga zawierająca opis dialektów włoskojęzycznej Szwajcarii, Lessico dei dialetti della Svizzera italiana, opublikowana w październiku 2004 roku, cieszyła się bardzo dużym powodzeniem wśród czytelników. Pomimo wysokiej ceny i dużych gabarytów została wyprzedana w ciągu kilku tygodni. W tym miejscu warto wspomnieć, że pozycja ta została opracowana i wydana przez Centrum Dialektologii i Etnografii (Centro di dialettologia e di etnografia), jednostkę badawczą mieszczącą się w Bellinzonie, finansowaną ze środków nie federalnych, ale kantonalnych. Lokalne dialekty 
włoskie, choć w aspekcie socjolingwistycznym stanowią mikroczęść obecnej rzeczywistości kantonu, cieszą się nadal wielką estymą wśród Ticinian.

Poza publikacjami o charakterze naukowym Ticinianie podjęli także wysiłek wydania książki o dialektach skierowanej dla najmłodszych. Przykładem może być seria książek popularyzatorskich, prezentująca dialekty z Ticino w kolorowej i wielojęzycznej wersji obrazkowej. Prezentowany tutaj rysunek (por. rys. 1) to okładka drugiej części książki przedstawiającej w komiczny sposób przysłowia ticińskie, z których każde opatrzone jest zabawnym rysunkiem i każde tłumaczone jest na języki: angielski, francuski, niemiecki, hiszpański oraz włoski standardowy.

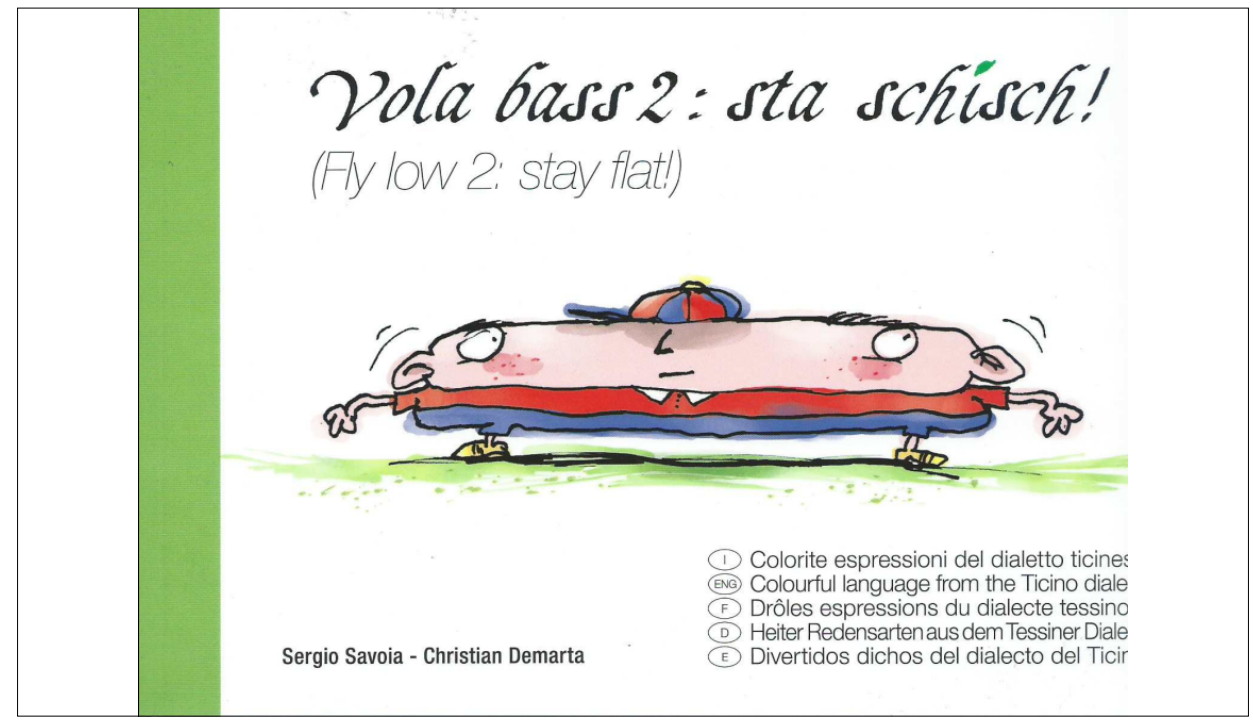

Rys. 1. Okładka wielojęzykowej książki prezentującej przysłowia i powiedzenia $\mathrm{w}$ dialektach z Ticino w tłumaczeniach na języki narodowe Szwajcarii oraz angielski. Źródło: archiwum autorki

Kwestią nie do pominięcia są również implikacje polityki językowej w Ticino w kontekście etnolektu niemieckich Walserów (w lokalnym brzmieniu - ggurijnartisch). Jako język zagrożony wymarciem znajduje się on pod specjalną ochroną w wyniku podpisanej i ratyfikowanej przez Szwajcarię Europejskiej Karty Języków Regionalnych lub Mniejszościowych. Pomimo to władze kantonu zdecydowały o nie powzięciu żadnych specjalnych środków na rzecz promowania walzerskiego niemieckiego z Bosco Gurin, argumentując m.in., że ze względu na depopulację nie jest to już nawet główny język w tej wsi i trudno by było uwierzyć, że jakiekolwiek działania rewitalizacyjne odniosłyby skutek. Z drugiej zaś strony przytaczany jest argument, że byłoby to działanie sprzeczne w przypadku kantonu, który otrzymuje dofinansowanie od rządu centralnego na ochronę swojego języka (włoskiego), który jest nie tylko językiem mniejszościowym w Konfederacji, lecz także znajduje się $\mathrm{w}$ trudnej fazie zmniejszania się liczebności swoich użytkowników. 
Nie oznacza to jednak, że władze kantonu nie interesują się sytuacją Bosco Gurin. Wspierają bowiem wydawanie publikacji, a także inną działalność odnoszącą się do kultury, historii oraz etnolektu walzerskich mieszkańców Bosco Gurin. Władze kantonu nawiązały współpracę z niewielkim guryńskim muzeum etnograficznym zwanym Walserhaus - gdyż mieści się ono w tradycyjnym walzerskim domu (por. fot. 2). Muzeum wyróżnia nie tylko lokalizacja i tematyka, ale również to, że w dużej mierze poświęcone jest ono językowi z Bosco Gurin, co czyni je wyjątkowym na tle innych ticińskich muzeów lokalnych poświęconych lokalnym dialektom o proweniencji włoskiej.

Muzeum guryńskie zorganizowało część przestrzeni wystawienniczej w formie ilustrowanego słownika, by w ten sposób zapisać stopniowe zanikanie lokalnego etnolektu oraz zaprezentować ważne dla Walserów przedmioty, z których niektóre wyszły już z użycia, gdyż pochodzą z dawnej, twardej rzeczywistości pracy na roli w wysokich górach. Przedmioty są prezentowane w swojej postaci lub jako zdjęcia i rysunki, a towarzyszą im odpowiednie wyjaśnienia odnośnie do przeznaczenia i sposobu ich użytkowania. Nowością są udostępnione dla zwiedzających przewodniki audio umożliwiające wysłuchanie przykładowych wyrażeń i wyjaśnień w dialekcie guryńskim. Podobnie jak w innych muzeach etnograficznych poświęconych konkretnym dialektom z Ticino, Walserhaus został utworzony, by utrwalić pamięć o etnolekcie Walserów i ich kulturze z czasów minionych.

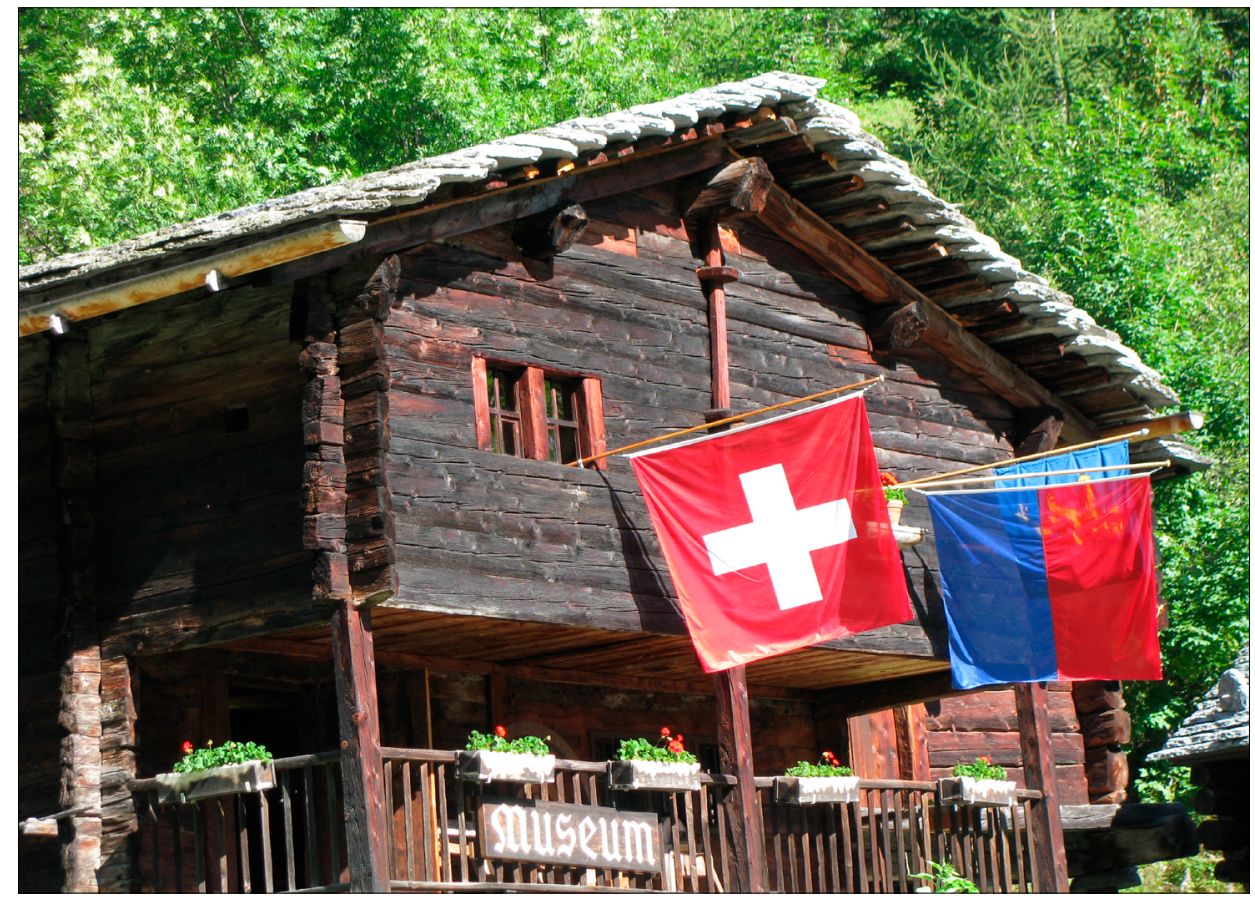

Fot. 2. Muzeum Walserów, ich języka i kultury w Ticino. Bosco Gurin, 2009.

Źródło: archiwum autorki 
Władze kantonu konsultowały możliwość dalszego rozwoju dialektu z ekspertami, m.in. Bruno Morettim i Sandro Bianconim, którzy uznali, że wieś ma bardzo małe szanse na długotrwałe utrzymanie językowej odrębności. Odpowiedzialność za dalszy los etnolektu mieszkańców tej wioski władze Ticino przenoszą na rząd federalny, który przyjął na siebie ten m.in. finansowy ciężar. Przez podpisanie oraz ratyfikowanie opisanego wcześniej dokumentu Europejskiej Karty Języków Regionalnych lub Mniejszościowych Szwajcaria zobowiązana jest do udzielenia pomocy dla lokalnego wariantu Walsersprache, który jako dialekt języka niemieckiego na obszarze włoskojęzycznego kantonu Ticino jest traktowany jako język mniejszościowy zagrożony wyginięciem.

\section{Poglądy i wyobrażenia mieszkańców o językach Ticino}

$\mathrm{W}$ świetle danych podawanych przez statystyki oraz wynikające $\mathrm{z}$ analiz badaczy zjawisk językowych i socjolingwistycznych żywotność języka włoskiego jest obecnie względnie bezpieczna - przynajmniej w samym kantonie. Perspektywa historyczna pokazuje jednak, że włoski długo walczył o tę pozycję i nieraz zagrażały mu inne etnolekty. Szczególnego znaczenia dla kwestii językoweje ${ }^{20} \mathrm{~W}$ regionie, jak i losów poszczególnych etnolektów nabiera polityka językowa prowadzona na najniższym szczeblu - oddolnie, przez samych użytkowników języka. Indywidualne decyzje podejmowanie przez mieszkańców Ticino odnośnie do użycia danego etnolektu w określonej sytuacji oraz ich stosunek do tego języka są kwestiami kluczowymi dla obecnej i przyszłej sytuacji językowej regionu oraz tożsamości językowo-kulturowej jego mieszkańców.

Badacze sfery planowania i polityki językowej, w skrócie PPJ (Language Planning and Policy, LPP), stosują trzy pojęcia, by poddać tę zależność teoretycznej analizie (McCarthy, Warhol 2011): pierwszy to tzw. orientacje językowe - oznaczają one podświadome inklinacje roli języka lub języków w danej społeczności; drugi to postawy względem języków lub postawy językowe, indywidualne odczucia w stosunku do swojego i innych języków; trzeci to ideologie językowe, czyli racjonalizowane przez użytkowników poglądy o języku; ideologie to inaczej także zależne od kontekstu kulturowego poglądy na język, na funkcjonowanie komunikacji językowej w danej wspólnocie czy uważane za oczywiste założenia o tym, jak język działa, jaki ma status.

Wszystkie te trzy terminy nie służą opisowi samego języka, lecz raczej obrazują tożsamość indywidualną, zbiorową i/lub też relacje władzy. Omawiając wyniki badań, pragnę skupić się na pokazaniu przede wszystkim ideologii i postaw, które prezentują mieszkańcy Ticino w stosunku do języka regionu i języka dominującego w danym kraju. Przedstawiam syntezę informacji z wywiadów dotyczących takich kwestii jak: edukacja oraz preferowane języki do nauki, dyskryminacja

${ }^{20}$ Zagadnienia związane z pojęciem kwestii językowej szczegółowo omawia np. Roman Szul (2003). 
językowa, ochrona języka i dziedzictwo kulturowe, języki charakterystyczne dla regionu oraz ważne dla mieszkających tam osób i dla przybywających imigrantów. Pokażę także, jak rozumiana jest wielojęzyczność, co w przyszłości może mieć wpływ na stopniową zmianę sytuacji językowej regionu oraz rolę poszczególnych etnolektów w życiu jego mieszkańców.

Analiza sądów mieszkańców Ticino obejmuje ich stosunek do oraz interpretacje pojęcia wielojęzyczności, które kojarzy się z mieszkańcami Szwajcarii (Barbour 2002). Rozmówców z Ticino podzieliłam na dwie grupy ze względu na ich preferowany język rozmowy: dominujący w regionie - włoski oraz dominujący w skali kraju, ale mniejszościowy w Ticino - niemiecki. W kontaktach z mieszkańcami Ticino posługiwałam się wersjami standardowymi tych etnolektów. W kilku przypadkach moi rozmówcy, starsi mieszkańcy górskich dolin, odpowiadali na moje pytania $\mathrm{w}$ jednym $\mathrm{z}$ licznych, coraz rzadziej używanych dialektów. Nieocenioną pomocą w tych rozmowach byli moi „przewodnicy międzykulturowi", przyjaciele poznani podczas pobytów w Ticino, którzy czasami pełnili rolę moich pośredników $\mathrm{w}$ umawianiu się na takie rozmowy i pomagali w konwersacji.

Zapytani o rozumienie terminu „wielojęzyczność" rozmówcy z Ticino chętnie podejmowali się przedstawienia swojej interpretacji tego pojęcia. Zdawali się uważać odpowiedź za oczywistą - wielu prawie automatycznie łączyło ją z formalnoprawną sytuacją Szwajcarii jako kraju konstytucyjnie wielojęzycznego, a także z faktem nie formalnej, lecz realnej wielojęzyczności w codziennym życiu kantonu. Wielu rozmówców z Ticino uważa wielojęzyczność przede wszystkim za swoją cechę: „Na przykład ja jestem wielojęzyczną osobą, częściowo z powodu przeprowadzki do innego regionu językowego, a częściowo poprzez podróże i znajomych" (Cimalmotto, M.41n ${ }^{21}$ ).

Niektórzy rozmówcy deklarowali, że są wielojęzyczni, ponieważ są Szwajcarami - niejako z zasady. Czasami po krótkiej rozmowie okazywało się, że np. znajomość innego język narodowego wśród niektórych osób uważających się za wielojęzyczne była tylko bierna. W mniejszym stopniu wielojęzyczność była traktowana jako właściwość danej przestrzeni. Natomiast wielu mieszkańców Ticino wskazywało, że jeśli ktoś chce mieszkać i pracować w tym regionie, koniecznie musi znać kilka języków, wielojęzyczność traktowana jest tutaj jako wymóg wynikający z turystycznego ukierunkowania ekonomii kantonu.

My z Ticino i włoskojęzycznej Szwajcarii jesteśmy mniejszością, więc to oczywiste, że musimy znać też inne języki, trochę niemieckiego i francuskiego, a bez znajomości angielskiego młodym ludziom byłoby trudno, dobrze więc, że w szkole uczą różnych języków. Kanton Ticino to kanton turystyki - aby upewnić się, że goście czują się u nas komfortowo, powinniśmy mówić przynajmniej językami Szwajcarii. (Cavergno, K.24w)

\footnotetext{
${ }^{21}$ Informacje o rozmówcach zakodowałam w następujący sposób: miejscowość, płeć (K - kobieta, $\mathrm{M}$ - mężczyzna), wiek, język rozmowy (w - włoski, $\mathrm{n}$ - niemiecki).
} 
Powinniśmy znać wiele języków, a także dialekty. Dlaczego? Bo jesteśmy krajem turystycznym, a także dla lepszego zrozumienia innych mieszkańców Szwajcarii. (Locarno, K.24w)

Kanton Ticino jest zorientowany turystycznie: byłoby pożądane zarówno ze względów kulturalnych, jak i ekonomicznych, żeby Ticinianie potrafili porozumiewać się z odwiedzającymi nas turystami. (Ascona-Locarno, K.43w)

Wśród Ticinian dominuje podejście, że wielojęzyczność to przede wszystkim skuteczna, nie zaś perfekcyjna językowo komunikacja. Moi ticińscy rozmówcy chcieliby uczyć się w szkole przede wszystkim następujących języków obcych: angielskiego, niemieckiego, francuskiego. Pomagają one ogólnie w komunikacji międzynarodowej, a dwa ostatnie dominują w Szwajcarii. Wskazywano też na język hiszpański. Rozmówcy tłumaczyli, że jest to język popularny na świecie i łatwy do nauki ze względu na podobieństwo do włoskiego. Rzeczywiście, oba kody językowe należą do tej samej, romańskiej grupy językowej. Kilkanaście osób wskazało także na chęć nauki języka chińskiego, co świadczyć może o ich świadomości odnośnie do wzrostu znaczenia politycznego tego państwa w świecie. Język włoski w naturalny sposób traktowany jest jako język prowadzenia lekcji. To również przedmiot nauczania, traktowany podobnie jak lekcje języka polskiego w polskich szkołach, obejmujący głównie poznawanie włoskojęzycznej literatury, pracę nad poprawnością gramatyczną i stylistyczną itp.

W aspekcie dialektów należy zaznaczyć, że mieszkańcy miast coraz rzadziej się nimi posługują, opierając werbalną stronę swojego życia praktycznie na etnolekcie włoskim, który jest podstawowym językiem komunikacji w Ticino:

Włoski to nasz język ojczysty22 i jednocześnie język kultury włoskiej, która jest też i naszą kulturą. Niemiecki jest językiem zdecydowanej większości ludności Szwajcarii, dla nas jest ważny jako język kontaktów zawodowych umożliwiający kontakt z innymi częściami Szwajcarii. (Cevio, M.43w)

Osoby włoskojęzyczne z mniejszych miejscowości, w tym przede wszystkim z dolin alpejskich, dzielą swoją codzienną praktykę językową na: 1) sferę włoskojęzycznych kontaktów formalnych, zawodowych (u osób dorosłych) i edukacyjnych (u dzieci i młodzieży) oraz wszelkich innych kontekstów oficjalnych; 2) sferę uży wania dialektu - domową, intymną, do której zaliczają się członkowie rodziny, przyjaciele, osoby bliskie. Oczywiście czasami się one mieszają, a etnolekt, jakim posługują się w określonej konwersacji mieszkańcy Ticino, zależy od konkretnej sytuacji.

\footnotetext{
${ }^{22}$ Dosłownie rzecz ujmując, jest to język „matczyny”, jako że rozmówca użył włoskiego określenia: lingua madre.
} 
Dla nas, z Ticino, rzeczą normalną jest używanie włoskiego w szkole oraz w rozmowie z ludźmi, których nie znamy dobrze. Dialektem mówimy u siebie w domu, na wsi, w sklepie i na przykład na poczcie. (Cavergno, K.24w)

Najczęściej w domu mówię dialektem, a poza nim po włosku. Ale zależnie od sytuacji używam tych języków też zamiennie. (Intragna, K.29w)

Mówienie w dialekcie jest jednak coraz rzadsze także i w sferze rodzinnej. Przez setki lat ludność żyła w dużej izolacji, poszczególne wioski wykształciły swoje własne dialekty. Obecnie, gdy zmiana miejsca zamieszkania i chęć podróżowania są dużo większe, jest coraz więcej rodzin mieszanych. Zdarza się, że gdy małżonkowie pochodzą z innych miejscowości, nie potrafią się porozumieć, mówiąc do siebie w swoich dialektach, gdyż są one zbyt różne, by umożliwić płynną komunikację:

Używam włoskiego i dialektu w rozmowach z rodziną i przyjaciółmi, wybór zależy od konkretnej sytuacji. Z żoną rozmawiam po włosku, a z moimi dziećmi w dialekcie. To dlatego że moja żona nie zna mojego dialektu. Znając bardzo dobrze oba te języki, automatycznie zmieniam jeden na drugi, nawet tego nie zauważając. Tak samo jest, gdy rozmawiam z przyjaciółmi. Generalnie zależy to od konkretnej sytuacji, w której się akurat znajduję. (...) Ogólnie mówiąc, jest tak, że podczas wydarzeń bardziej oficjalnych automatycznie przełączam się na włoski, a w sytuacjach codziennych mówię dialektem. (Cevio, M.43w)

Zmienność używania języków w zależności od sytuacji, czyli tzw. przełączanie (z ang. code-switching), jest zjawiskiem typowym dla osób żyjących w środowiskach wielojęzycznych, w tym dla osób pochodzących z rodzin mieszanych (kulturowo i językowo). Takie sytuacje są dość często spotykane także w Ticino. Wśród osób władających np. włoskim i niemieckim, przyczyny zmiany języka bywają też bardziej prozaiczne, jak np. większa dostępność prasy, książek czy kanałów telewizyjnych:

Ponieważ moimi językami ojczystymi są włoski i niemiecki, często używam tych języków zamiennie, np. zależy, jaka książka jest dostępna - w takim języku czytam. Telewizję oglądam po niemiecku, ale to dlatego że telewizja niemieckojęzyczna jest lepsza od włoskiej. (Muralto, K.28w)

Chociaż według moich rozmówców najważniejszym językiem w Ticino, zarówno na poziomie symbolicznym, jak i komunikacyjnym, jest język włoski, niektóre grupy osadników niemieckojęzycznych, które przybyły do Ticino, by spędzić w nim okres emerytury, zachowują jednojęzyczność, nie podejmując wysiłku nauczenia się lokalnego etnolektu. Od tej reguły są jednak - i to dość liczne - wyjątki. Niektórzy niemieckojęzyczni mieszkańcy kantonu uczą się włoskiego, gdyż uważają, że „włoski jest najważniejszy dla integracji z mieszkańcami 
kantonu” (Locarno, M.59n); lub że „wszyscy Szwajcarzy powinni umieć mówić (poza niemieckim) także po włosku i francusku, jesteśmy przecież krajem czterojęzycznym" (Cimalmotto, M.41n). Jeden z innych moich niemieckojęzycznych rozmówców, który należał do takich wyjątków, nie prowadzi życia zamkniętego w obrębie swojej grupy etnicznej, wręcz przeciwnie, osiedlił się wraz ze swoją partnerką w samym centrum włoskojęzycznego Locarno i podjął wysiłek nauki włoskiego. Inna niemieckojęzyczna para przyjęła podobną strategię językową, by zintegrować się z mieszkańcami wsi, w której zdecydowali się zamieszkać:

My jako „emigranci” mówimy: nie trzeba znać włoskiego w sposób doskonały, ale gdy nauczyliśmy się w nim porozumiewać, to zyskaliśmy akceptację lokalnych mieszkańców, można powiedzieć, że dzięki temu nasza integracja z życiem wsi (mieszkamy na wsi w dolinie) w ogóle była możliwa. (Prato-Sornico, M.54n)

Kolejnym przykładem wyjątku od przedstawionej wyżej reguły stanowią rozmówcy z położonej wysoko w Alpach farmie nastawionej na ekologiczną produkcję. Założyli ją kilkadziesiąt lat temu, ponieważ chcieli zrealizować marzenie życia po przeprowadzce do Ticino spod Zurychu. W życiu codziennym wśród rodziny i wolontariuszy, którzy przybywają z całego kraju, żeby pomóc przy pracach rolniczych, używają głównie szwajcarskiej odmiany języka niemieckiego. Jednak kilkudziesięcioletnie zakorzenienie $\mathrm{w}$ regionie, posyłanie do włoskojęzycznej szkoły dzieci, nawiązywanie relacji sąsiedzkich i biznesowych, sprawiło, że rolnicy nauczyli się także języka włoskiego, który przydaje im się jako język relacji pozarodzinnych.

Zagadnieniem, które poruszałam w rozmowach z mieszkańcami szwajcarskiego kantonu, była także kwestia ochrony języków na jego obszarze. Wśród niemieckojęzycznej mniejszości żyjącej wśród Ticinian, kilkukrotnie pojawiały się uwagi, że chroniony powinien być przede wszystkim etnolekt: „niemiecki Walserów z Bosco Gurin, wsi położonej w Dolinie Valle Maggii" (Peccia, M.61n); ponieważ: „młodzi już nie mówią za dużo w tym języku” (Cimalmotto, M.37n). Rzeczywiście, od kilkunastu lat w sferze językowej niemieckojęzycznych mieszkańców walserskiej wioski Bosco Gurin zachodzą poważne zmiany - zanika używanie etnolektu, zastępuje go natomiast język włoski, szczególnie wśród młodych mieszkańców. Przez wiele lat działała w niej mała lokalna szkoła, w której zajęcia - jak we wszystkich szkołach w Ticino - prowadzone były po włosku. Natomiast dodatkowo mali Walserczycy mieli $w$ ramach programu nauczania dwie dodatkowe lekcje języka niemieckiego standardowego w tygodniu.

Depopulacja wioski spowodowała, że liczba uczniów spadła drastycznie i kilka lat temu szkołę zamknięto. Dzieci zaczęły uczyć się w szkole położonej poniżej ich wioski, w dole doliny, Cevio. Zrezygnowano z opcji dodatkowych lekcji niemieckiego na wniosek rodziców, którzy okazali się sceptyczni wobec dwujęzycznej edukacji dzieci. Jako powód swojej decyzji podali spadającą liczbę użytkowników niemieckiego w Ticino oraz to, że niemiecki język standardowy 
nie jest i nigdy nie był ich językiem. Jest nim dialekt Walsersprache, natomiast Hochdeutsch pojawił się dopiero wraz z edukacją, w formie pisanej.

Nauczanie walserskiego nastręcza wiele trudności, począwszy od wyboru odpowiedniego wariantu, znalezienia odpowiednio wykształconego nauczyciela, który mógłby go nauczać. Do tej pory nie udało się takiej osoby zatrudnić. Kolejnym powodem rezygnacji z dodatkowych godzin standardowego niemieckiego była chęć oszczędzenia czasu oraz trudu - dodatkowe lekcje oznaczały dodatkowy czas w szkole, który dla dojeżdżających z gór dzieci oraz ich rodziców był bardzo cenny - w niektórych sytuacjach, dzieci nadal pomagają rodzicom w pracy. Codzienne dojazdy do szkoły przy dużej zmianie wysokości wpływają negatywnie na samopoczucie i zdolności do nauki. Jeden z dorosłych mieszkańców sąsiedniej miejscowości, który jako dziecko również musiał codziennie dojeżdżać do szkoły, w rozmowie ze mną skarżył się, że źle to wpływało na niego i na rodzeństwo, powodowało bóle głowy i inne dolegliwości. Wyprowadził się $\mathrm{z}$ rodziną do jednej z dolin, natomiast na farmie w górach spędza okres letnich wakacji szkolnych.

Z kolei język włoski, według znakomitej większości rozmówców z Ticino, nie jest językiem zagrożonym - przynajmniej na terenie ich kantonu. Jakiekolwiek przejawy niepokoju o jego dalszy los informatorzy odnosili raczej do jego sytuacji w pozostałej części Szwajcarii.

Ochrony wymaga włoski, ale nie w Ticino, tylko w Szwajcarii. Włoski jest jednym z czterech języków Szwajcarii, a mimo to mam wrażenie, że jest trochę pomijany i rzadko używany. (Monte Carasso, M.48w)

Obawa o losy włoskiego w wielojęzycznej federacji to jednak postawa znamienna przede wszystkim dla przedstawicieli ticińskiej inteligencji. Wyrazili ją w rozmowach ze mną zarówno przedstawiciele lokalnej administracji, jak i badacze, w szczególności pracownicy Osservatorio linguistico della Svizzera italiana - instytucji zajmującej się monitorowaniem sytuacji języka włoskiego.

Wspomnieni rozmówcy, zarówno włosko-, jak i niemieckojęzyczni, uważali, że przede wszystkim polityka językowa powinna objąć ochroną lokalne dialekty. Traktowane są one i przez mieszkańców, i przez władze regionu jako jego dziedzictwo kulturowe, gdyż: „stanowią one część kultury Ticino” (Locarno, K.24w); jak również „wyróżniają Ticino na tle innych kantonów, a włoski jest językiem naszych sąsiadów, Włoch, i jest językiem o bogatej historii” (Lugano, K.20w).

W Bellinzonie istnieje jednostka naukowa zajmująca się tak badaniem języka włoskiego w Ticino, jak i stanem dialektów. Jednak to zdecydowanie za mało, by umożliwić dialektom uczciwe konkurowanie z włoskim standardowym. 


\section{Podsumowanie}

Włoskojęzyczni Ticinianie są silnie zżyci ze swoim językiem, ale nie jest to bezpośrednia zasługa działań władz ani też wdrażania językowych aktów prawnych, raczej ugruntowanej historycznie roli tego języka jako wyróżnika kulturowego regionu. Ticinianie są dumni także z bycia Szwajcarami. Ich tożsamość płynnie łączy tę etniczną i kulturowo-językową (włoską) z ponadregionalną, narodową (szwajcarską). W tym niejako symbolicznym kontekście podkreślają, że są wielojęzyczni - nawet wówczas, gdy faktyczne umiejętności językowe są mocno ograniczone, czy to do znajomości biernej, czy to do ograniczonego słownictwa $\mathrm{w}$ danym etnolekcie. Włoskojęzyczny charakter regionu zdają się akceptować również mieszkający w Ticino przedstawiciele mniejszości niemieckojęzycznych, nawet ci spośród nich, którzy nie podejmują wysiłku, by opanować dominujący $\mathrm{w}$ regionie etnolekt.

Polityka językowa, przejawiająca się w działaniach lokalnych, wpływa więc w niewielki sposób na stosunek mieszkańców kantonu w Ticino. Projekty władz kantonu związane z kwestiami językowymi są wciąż w początkowej fazie rozwoju. Zamierzonym efektem planowanych działań edukacyjnych i promocyjnych zdaje się być przede wszystkim zwiększanie znajomości języka włoskiego $\mathrm{w}$ innych częściach kraju oraz uzyskanie wyższej pozycji dla niego w hierarchii języków na poziomie państwowym. Bowiem język włoski, mimo statusu języka urzędowego Szwajcarii, poza obszarem Svizzera Italiana nie cieszy się wysokim prestiżem i rzadko jest używany.

W podejściu mieszkańców Ticino do języków coraz większego znaczenia nabiera funkcja symboliczna danego etnolektu - jako nośnika tożsamości, symbol prestiżu i możliwości. Stąd m.in. tak duża akceptacja dla wersji literackiej włoskiego, promowanego także lokalnie (np. w edukacji, jako język nauki w szkołach publicznych), nawet kosztem odmiany regionalnej czy dialektów. Toteż działania polityki językowej $\mathrm{w}$ regionie skupiają się przede wszystkim na promocji zewnętrznej włoskiego literackiego. Dla regionu, który wciąż jest traktowany jako prowincja Szwajcarii, ten język stanowi cenny potencjał w sferze m.in. ekonomicznej czy turystycznej (w tym turystyki edukacyjnej).

Działania skierowane na rzecz zachowania i podniesienia prestiżu lokalnych odmian języka i dialektów mają głównie charakter naukowy (badanie, analiza, publikacje), w mniejszym stopniu - edukacyjne czy promocyjne. W niewielkim zakresie działania językowe obejmują promowanie, tudzież wspieranie praktycznej wielojęzyczności, która zdecydowanie umożliwiłaby kantonowi większą integrację na poziomie zarówno krajowym, jak i międzynarodowym. Natomiast wielojęzyczność per se, odnosząca się np. do konstytucyjnej wielojęzyczności Szwajcarii, ma swoje odbicie wszystkim w komunikacji życia codziennego rodzin wielokulturowych, których członkowie uważają, że znajomość kilku etnolektów to cenny dar, ułatwiający i wzbogacający ich życie.

W prezentowanym tekście, ze względu na ograniczenia rozmiarowe, omówiłam jedynie te etnolekty, które są ważne dla ludności miejscowej, a jednocześnie 
ujmują je działania ticińskich decydentów polityki językowej. Zasygnalizowana jedynie została rola języka angielskiego w życiu mieszkańców Ticino powszechnie kojarzonym jako język kontaktów międzynarodowych. Nierzadko to on spełnia funkcję lingua franca w komunikacji między rodakami-Helwetami z różnojęzycznych kantonów, bardziej efektywnie niż np. niemiecki ${ }^{23}$, o czym niejednokrotnie wspominali moi rozmówcy. Jest widoczny i słyszany w Ticino częściej niż drugi konstytucyjny język Helwecji - francuski ${ }^{24}$. Zabrakło miejsca na omówienie m.in. roli języków imigrantów, licznie przybywających do Ticino ich etnolekty bowiem nie są głównym przedmiotem troski polityki językowej w regionie.

Ticiniane to na co dzień społeczność dyglosyjna i wielojęzykowa; zapewne taki stan rzeczy utrzyma się przez pewien czas, czemu sprzyjać będzie m.in. peryferyjność regionu, izolacja wielu małych miejscowości położonych w Alpach czy wreszcie - duma i przywiązanie do wartości rodzimych, symbolizowanych m.in. przez odniesienia do włoskiego języka i kultury w dokumentach prawnych.

Przewiduję, że włoski - w szczególności wariant regionalny i literacki - pozostanie charakterystyczną cechą kantonu Ticino i wyróżnikiem kulturowym (językowym) znakomitej większości jego mieszkańców. Będzie się on jednak coraz bardziej ujednolicał, a dialekty z czasem będą zanikać, na co zapewne wpłynie m.in. zwiększająca się liczba imigrantów włosko- oraz niemieckojęzycznych, a także inne efekty postępującej globalizacji ${ }^{25}$ (obecnej także w świecie wirtualnym w Ticino). Wpływają one przecież na wybory życiowe, w tym językowe, młodego pokolenia. A to właśnie przede wszystkim od postawy i wpływających na nie poglądów językowych młodych zależy przyszłość językowa i kulturowa regionu oraz losy jego niematerialnego dziedzictwa, jaką są lokalne etnolekty i ich bogactwo (Dołowy-Rybiński 2014). Czy w świecie dążącym do uproszczenia i przyspieszenia młodzi znajdą na to siłę, czas i chęci, pokaże przyszłość. $\mathrm{Z}$ pewnością ten aspekt tożsamości językowo-kulturowej regionu Ticino i jego mieszkańców wart byłby dalszych badań.

\section{Literatura}

Barbour, S. (2002). Germany, Austria, Switzerland, Luxemburg: The Total Coincident of Nations and speech Communities? W: S. Barbour, C. Carmichael, Language and Nationalism in Europe. Oxford: Oxford University Press, 152-167.

\footnotetext{
${ }^{23}$ Nie pełni tej roli niemiecki, gdyż rozdrobnienie dialektalne $w$ ramach Schwyzerdütsch jest zbyt duże, by umożliwić wzajemnie porozumienie, a wariantem oficjalnym w wersji pisanej oraz innych kontekstach, np. dubbingowanych programów telewizyjnych jest Hochdeutsch.

${ }^{24} \mathrm{~W}$ przestrzeni Ticino nieobecny jest retoromański, czwarty język dla Szwajcarii według ich konstytucji.

${ }^{25}$ Jej efekty to wyzwanie nie tylko dla Ticinian, ale dla wszystkich Szwajcarów, szczególnie w kontekście tradycyjnej polityki językowej prowadzonej na podstawie konstytucyjnej czterojęzyczności tego kraju (por. np. Zieliński 2004).
} 
Beffa, J. (2015). La grammatica italiana per le Scuole maggiori e i Ginnasi di Bruno Migliorini e Giuseppe Mondada: Uno studio di caso. Master thesis. Lugano: Scuola universitaria professionale della Svizzera italiana (SUPSI).

Benedicts, A. (1997). Wspólnoty wyobrażone: rozważania o źródtach i rozprzestrzenianiu się nacjonalizmu. Tłum. S. Amsterdamski. Kraków: Społeczny Instytut Wydawniczy; Warszawa: Fundacja im. Stefana Batorego.

Bianconi, S. (1980). Lingua matrigna italiano e dialetto nella Svizzera italiana. Bologna: Il Mulino.

Bianconi, S. (1989). I due linguaggi: Storia linguistica della Lombardia Svizzera dal'400 ai nostri giorni. Bellinzona: Edizione Casagrande.

Bianconi, S. (2001). Lingue di frontiera. Una storia linguistica della Svizzera italiana dal Medioevo al Duemilla. Bellinzona: Casagrande.

Bianconi, S. (ed.) (1994). Lingue nel Ticino. Un'indagine qualitativa e statistica. Locarno: Osservatorio linguistico della Svizzera italiana.

Burszta, W. (1986). Jezzyk a kultura w myśli etnologicznej. Wrocław: Polskie Towarzystwo Ludoznawcze.

Casoni, M. (2003). L'italiano nei siti web. Bellinzona: OLSI.

Catricalà, M. (1995). L'italiano tra grammaticalità e testualizzazione. Il dibattito linguistico-pedagogico del primo sessantennio postunitario. Florencja: Accademia della Crusca.

Ceschi, R. (2006). Le nostre origini. Le terre ticinesi dai tempi remoti alla fine del Settecento. Locarno: Armando Dadò editore.

Dołowy-Rybiński, N. (2014). Młodzi Kaszubi i język - dylematy mikropolityki językowej. LUD, 98, 253-275.

European Charter for Regional or Minority Languages (1992). Council of Europe, Strasburg.

Ferguson, C. (1959). Diglossia. The Word Journal, 15(1), 325-340.

Franscini, S. (1989). La Svizzera italiana. Reedycja wydania pierwszego (Lugano: Ruggia, 1837). Op. Virgilio Gilardoni. Bellinzona: Casagrande.

Gajda, S. (1998). Promocja języka i kultury polskiej a proces uniwersalizacji nacjonalizacji kulturowo-językowej w świecie. W: J. Mazur (red.), Promocja języka i kultury polskiej w świecie. Lublin: Wydawnictwo Uniwersytetu Marii Curie-Skłodowskiej.

Gilardino, S. (ed.) (2005). Walsersprache 1: La lingua dei Walser: lo stato attuale delle conoscenze. Aosta: Le Chateau.

Kuntz, J. (2008). Switzerland. How an alpine pass became a country. Geneva: Historiator Editions.

Legge della scuola (del $1^{\circ}$ febbraio 1990). Il Gran Consiglio della Repubblica e Cantone Ticino (Ustawa o szkolnictwie z 1 lutego 1990 roku).

Lewis, M.P., Simons, G.F., Fennig, CH.D. (ed.) (2013). Ethnologue: Languages of the World, wyd. 17. Dallas: SIL International.

Linda, K. (2009). Kultura i język w aspekcie regionalnym. W: A.W. Brzezińska, A. Hulewska, J. Słomska-Nowak (red.), Edukacja kulturowa: przestrzeń - kultura - przekaz. Wrocław: Wydawnictwo Wyższej Szkoły Zarządzania „Edukacja”.

Linda, K. (2011). Polityka językowa w Hiszpanii na przykładzie języka katalońskiego i Katalonii. W: W. Dohnal, A. Posern-Zieliński, Antropologia i polityka. Szkice z badań nad kulturowymi wymiarami wtadzy. Warszawa: KNE PAN, 42-52.

Lurati, O. (1976). Dialetto e italiano regionale nella Svizzera italiana. Lugano: Banca Solari \& Blurn.

Lurati, O. (1982). Die sprachliche Situation der Südschweiz. W: Schläpfer R. (ed.), Die viersprachige Schweiz. Zürich: Benziger, 212-252. 
Lurati, O. (1994). Canton Ticino. W: F. Bruni (ed.), L'italiano nelle regioni. Testi e documenti. Torino: UTET.

Majewicz, A.F. (1989). Jezzyki świata i ich klasyfikowanie. Warszawa: Państwowe Wydawnictwo Naukowe.

Martinoni, R. (2011). La lingua italiana in Svizzera: cronache e riflessioni. Bellinzona: Fondazione Ticino Nostro.

McCarthy, T.L., Warhol, L. (2011). The Anthropology of Language Planning and Policy. W: B.A.U. Levinson, M. Pollock (eds.), The Anthropology of Language Planning and Policy A Companion to the Anthropology of Education. West Sussex: Blackwell Publishing Ltd, 177-196.

Moretti, B., Antonini, F. (2000). Famiglie bilingui: modelli e dinamiche di mantenimento e perdita di lingua in famiglia. Locarno: Osservatorio linguistico della Svizzera italiana.

Pawłowski, A. (2004). Język w konstytucjach wybranych państw europejskich. Poradnik Jezykowy, 4(613), 10-25.

Pedrazzini, M. (1952). La lingua italiana nel diritto federale svizzero. Locarno: Tipgrafia Pedrazzini.

Porębski, A. (2009). Wielokulturowość Szwajcarii na rozdrożu. Kraków: Wydawnictwo Uniwersytetu Jagiellońskiego.

Savoia, S., Vitale, E. (2008). Lo Svizzonario. Splendori, miserie e segreti della lingua italiana in Svizzera. Bellinzona: Tipografia Torriani SA.

Schinz, H.R. (1985). Descrizione della Svizzera Italiana nel settecento. Locarno: Dadò.

Silverstein, M. (1979). Language Structure and Linguistic Ideology. W: P. Clyne, W. Hanks, and C. Hofbauer (eds.). The Elements. Chicago: Chicago Linguistic Society, 193-248.

Staszczak, Z. (red.) (1987). Słownik etnologiczny. Terminy ogólne. Warszawa: Państwowe Wydawnictwo Naukowe.

Stähli, A. (2011). Aspetti di vitalità, mantenimento e perdita di una lingua. Riflessioni per un inquadramento sociolinguistico di Bosco Gurin, comune walser in Ticino. W: B. Moretti, E.M. Pandolfi, M. Casoni (ed.). Vitalità di una lingua minoritaria aspetti e proposte metodologiche (Vitality of a minority language aspects and methodological issues) (p. 211-226). Bellinzona: OLSI.

Stępkowska, A. (2013). Collective aspects of communication: The Italian-speaking Swiss. Poznańskie Spotkania Językoznawcze, t. 26.

Szmidt, D.T., Mejnartowicz, A. (2009). Europejska wielokulturowość i wielojęzyczność (European Multiculturalism and Multilingualism). Investigationes Linguisticae, XVIII, $80-88$.

Szul, R. (2003). Kwestia językowa we współczesnym świecie. Studia Regionalne i Lokalne 2(12), 29-55.

Szul, R. (2009). Język, naród, państwo. Język jako zjawisko polityczne. Warszawa: PWN.

Tomamichel, T. (1976). Bosco Gurin. Das Walserdorf im Tessin. Mit Zeichnungen von Hans Tomamichel. Vierte, ergaenzte Auflage. Frauenfeld: Hubner \& Co.AG.

USTAT: Ufficio di statistica del Cantone Ticino, http://www4.ti.ch/index.php?id=42380 (dostęp: 17.12.2015).

Wysoczański, W. (1999). Ekologia języka jako dyscyplina heterogenicznego opisu języka. Biuletyn Polskiego Towarzystwa Jezykoznawczego, 63-76.

Wysoczański, W. (2006). Wielojęzykowość i wielokulturowość pograniczy (w kontekście polskim). W: A. Burzyńska-Kamieniecka, A. Dąbrowska (red.), Język a kultura. Tom 18. Wielokulturowość w języku (s. 9-32). Wrocław: Wydawnictwo Uniwersytetu Wrocławskiego. 
Zieliński, L. (2004). Globalizacja jako wyzwanie wobec tradycyjnej polityki językowej czterojęzycznej Szwajcarii. W: B. Rowińska-Januszewska (red.), Między "rajem" a "więzieniem". Studia o literaturze i kulturze Szwajcarii (s. 413-427). Poznań: Wydawnictwo Poznańskie.

\section{SUMMARY}

Ticino, its inhabitants and their linguistic and cultural identity

The purpose of the article is to discuss and analyze the linguistic and cultural identity of Ticino and its inhabitants. The text presents the Swiss region and its language(s) from a historical and contemporary perspective, as well as two areas of language micro-policy: 1) implemented in the region by representatives of local elites/decision makers 2) present in the daily life of the inhabitants of Ticino: their decisions, views and attitudes towards languages. Discussion of these issues is based on the analysis of ethnographic research conducted in the region and existing documents and literature on the subject. I argue that although multilingualism is present in the region and in its inhabitants' beliefs and everyday life practices, it does not contradict the fact that Italian is considered to be culturally the most important distinguishing feature of Ticino and the main language of the canton. I conclude that language policy implemented at the regional and local level in recent times has had little impact on the linguistic and cultural identity of the region and its inhabitants.

Key words: Ticino, linguistic and cultural identity, anthropology of language policy 